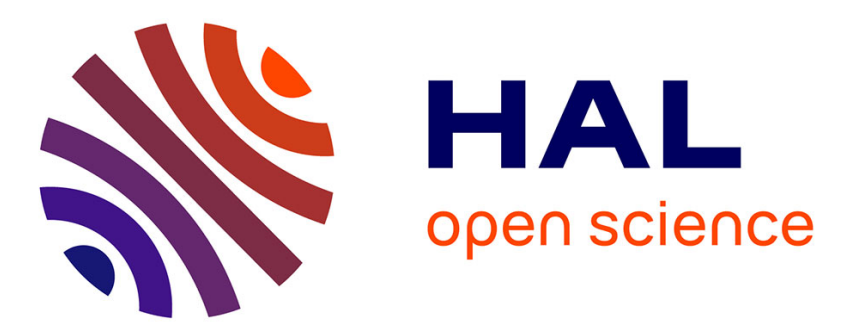

\title{
Clinical relevance of the putative stem cell marker p63 in breast cancer
}

\author{
L. Hanker, T. Karn, E. Ruckhaeberle, R. Gaetje, C. Solbach, M. Schmidt, K. \\ Engels, U. Holtrich, M. Kaufmann, A. Rody
}

\section{- To cite this version:}

L. Hanker, T. Karn, E. Ruckhaeberle, R. Gaetje, C. Solbach, et al.. Clinical relevance of the putative stem cell marker p63 in breast cancer. Breast Cancer Research and Treatment, 2009, 122 (3), pp.765775. 10.1007/s10549-009-0608-6 . hal-00535409

\section{HAL Id: hal-00535409 \\ https://hal.science/hal-00535409}

Submitted on 11 Nov 2010

HAL is a multi-disciplinary open access archive for the deposit and dissemination of scientific research documents, whether they are published or not. The documents may come from teaching and research institutions in France or abroad, or from public or private research centers.
L'archive ouverte pluridisciplinaire HAL, est destinée au dépôt et à la diffusion de documents scientifiques de niveau recherche, publiés ou non, émanant des établissements d'enseignement et de recherche français ou étrangers, des laboratoires publics ou privés. 


\title{
Clinical relevance of the putative stem cell marker p63 in breast cancer
}

\author{
L. Hanker - T. Karn • E. Ruckhaeberle $\cdot$ R. Gaetje • \\ C. Solbach • M. Schmidt • K. Engels $\cdot$ U. Holtrich • \\ M. Kaufmann $\cdot$ A. Rody
}

Received: 1 July 2009/Accepted: 15 October 2009/Published online: 7 November 2009

(C) Springer Science+Business Media, LLC. 2009

\begin{abstract}
P63 is a member of the p53 family. This protein is crucial for the maintenance of a stem cell population in the human epithelium and necessary for the normal development of all epithelial tissues including mammary glands. In normal breast tissue, the p63 seems to be a specific myoepithelial cell marker. P63 expression has been described in highly aggressive ER negative basal-like breast tumors. The value of p63 expression in ER positive disease is less clear. The expression levels of p63 mRNA by Affymetrix microarray analysis in a combined cohort of 2,158 ER positive breast cancers and its prognostic and predictive impact were analyzed. Tumor samples containing large amounts of benign breast tissue, which will interfere with p63 measurement, were excluded prior to the analysis. Survival analysis revealed a better prognosis of ER positive breast cancer expressing p63 $(n=410$; $P<0.036$ ). No correlation of p63 with standard parameters was observed. In a subgroup analysis, endocrine-
\end{abstract}

L. Hanker and T. Karn contributed equally.

Electronic supplementary material The online version of this article (doi:10.1007/s10549-009-0608-6) contains supplementary material, which is available to authorized users.

L. Hanker · T. Karn ( $)$ - E. Ruckhaeberle · R. Gaetje ·

C. Solbach · U. Holtrich · M. Kaufmann - A. Rody

Department of Obstetrics and Gynecology, J. W. Goethe-

University, Theodor-Stern-Kai 7, 60590 Frankfurt, Germany

e-mail: t.karn@em.uni-frankfurt.de

M. Schmidt

Department of Obstetrics and Gynecology,

J. Gutenberg-University, Mainz, Germany

K. Engels

Department of Pathology, J.W. Goethe-University,

Frankfurt, Germany treated patients with high p63 expression showed a better prognosis than low $\mathrm{p} 63$ expression $(P=0.06 ; n=186)$. In untreated patients, this effect was less clear $(n=148$; $P=0.5$ ). P63 is a positive prognostic factor in endocrinetreated ER positive breast cancer and might influence responsiveness to endocrine treatment. Thus, p63 could be helpful as a predictive factor for endocrine therapy.

Keywords p63 - TP73L $\cdot$ Stem cell $\cdot$ Microarray · Benign tissue

\section{Introduction}

The protein 63 (p63) represents a member of the p53 family (p53/p63/p73) located on chromosome 3q27 [1]. This gene family seems to play an important role in the carcinogenesis and may act at least in parts as oncogenes or tumor suppressor genes [1,2]. The p63 is the recent member of this family and few is known about this member. The human p63 gene expresses at least six mRNA variants which encode for six different p63 protein isoforms (TAp63 $\alpha$, TAp63 $\beta$, TAp63 $\gamma, \Delta \mathrm{Np} 63 \alpha, \Delta \mathrm{Np} 63 \beta$ and $\Delta \mathrm{Np} 63 \gamma)[3,4]$. These consist of three alternatively spliced C-terminal isoforms $(\alpha, \beta, \gamma)$ and can be classified in two groups generated by alternative promoter usage: The transactivating isoforms (TAp63) and the N-terminal truncated p63 isoforms $(\Delta \mathrm{Np} 63)$, which lack the transactivating $\mathrm{N}$-terminal region [5-7]. The translational products of p63 are crucial for the maintenance of a stem cell population in the human epithelium [8] and are necessary for the normal development of all epithelial tissues [9], including mammary glands $[10,11]$. The critical contribution to epithelial morphogenesis could be shown in mice null for $\mathrm{p} 63$, which presented with severe abnormalities at 
birth, i.e., truncation of the limbs, craniofascial malformations, and an absence of epidermis [8, 12]. Furthermore, p63 is expressed in the basal epithelial cells of the skin, the cervix, and the prostate as well as in the myoepithelial layer of normal breast ducts and lobules [10, 11].

Only a few authors described p63 expression in the mammary glands. For example, this protein was found in a subset of highly aggressive ER negative breast cancers that represent a basal and myoepithelial phenotype and have a poor clinical outcome $[13,14]$. In normal breast tissue, p63 seems to be a specific myoepithelial cell marker [15]. Some authors were able to identify p63 and other myoepithelial cell markers in matrix-producing and metaplastic carcinomas of the breast, suggesting that these tumors have in common a myoepithelial cell differentiation [16]. Ribereiro-Silva et al. confirmed p63 as a specific myoepithelial marker in normal breast tissue which is rarely overexpressed in grade 3 invasive ductal carcinomas [15].

Nevertheless, the role of p63 in neoplasia, especially in breast cancer, is not clearly described. The potential role of p63 as a tumor suppressor gene or as an oncogene has been discussed. There are conflicting results of two independent studies with p63 deficient mice. In the study of Flores et al., these mice were found to have a tendency to develop a tumor formation and metastasis [17]. On the other hand, Keyes et al. showed no evidence of a predisposition to tumor growth in mice null for p63 [18]. Although there is an abundance of reports of p63 overexpression in many different tumors, above all in squamous cell carcinoma like head and neck cancer [19], lung cancers [20], cutaneous tumors [21], uterine tumors [22, 23], and breast cancer [15, $24,25]$, it seems to be clear that p63 is very rarely mutated in cancers [26].

Here, we investigated the expression levels of p63 mRNA by Affymetrix microarray analysis in a combined cohort of 2,158 ER positive breast cancers and its prognostic and predictive impact. We observed no correlation of p63 expression with age, tumor size, histological grading as well as progesterone receptor, and HER2 status in the ER positive subgroup of patients. Our findings indicate a better prognosis for patients with higher expression of p63. Moreover, the analysis of treated and untreated patients points to a role of $\mathrm{p} 63$ in endocrine responsiveness.

\section{Materials and methods}

\section{Breast cancer samples}

Tissue samples of invasive breast cancer cases were obtained with IRB approval and informed consent from consecutive patients undergoing surgical resection between December 1996 and July 2007 at the Department of
Gynecology and Obstetrics at the Goethe-University in Frankfurt. All tissue samples were stored in liquid nitrogen. Samples were characterized according to the standard pathology including the estrogen receptor status by ligandbinding assays or immunohistochemistry.

\section{Microarray data}

A database of $n=3030$ Affymetrix HG-U133A microarrays from treatment-naïve primary breast cancer samples was established, as we have recently described [27]. We included 238 of our own samples (datasets Frankfurt, Frankfurt-2, and Frankfurt-3) which have been described previously [28-32] as well as 2,792 samples from 22 different publicly available datasets (Supplementary Table S1) [33-56]. Affymetrix expression data were analyzed by using the MAS5.0 [57] algorithm of the affy package [58] of the Bioconductor software project [59] (http://www. bioconductor.org/). Subsequently data were $\log _{2}$ transformed and median centered. To adapt different datasets the expression values of all the genes on the array were multiplied by a scale factor $\mathrm{S}$ so that the magnitude (sum of the squares of the values) is equal for each array. The clinical characteristics of the patients in the different datasets are also summarized in Supplementary Table S1. The ER status, PgR status, and HER2 status was determined by microarray as described previously [27]. The subset of 2,158 ER positive tumors was selected for this study from the complete database of 3,030 samples. For comparison, data from $n=140$ normal breast biopsies were also used [56].

P63 is indicated by six different probe sets on the Affymetrix HGU133A microarray. These different sets represent the p63 isoforms in various grades, but are not able to discriminate between them (Fig. 1a). Only two of these probe sets, 209863_s_at and 211194_s_at, both detecting the same p63 isoforms, strongly hybridized to mRNA from breast tumor samples. In addition, published data from $\mathrm{p} 63$ knockdown experiments through RNAi in several cell lines $[60,61]$ demonstrate that the largest fold change is observed for probeset 209863_s_at (Fig. 1b). Since this probeset also had the highest dynamic range in breast cancers, it was chosen for all further analysis.

Statistical analyses

All analyses were performed following the REMARK recommendations for tumor marker studies [62]. Follow-up data were available for 1,548 of the 2,158 ER positive samples (11 datasets without follow-up, see Supplementary Table 1). For nine datasets relapse free survival (RFS) was used as an endpoint $(n=919)$, while for five dataset only distant metastasis free survival (DMFS) was available 

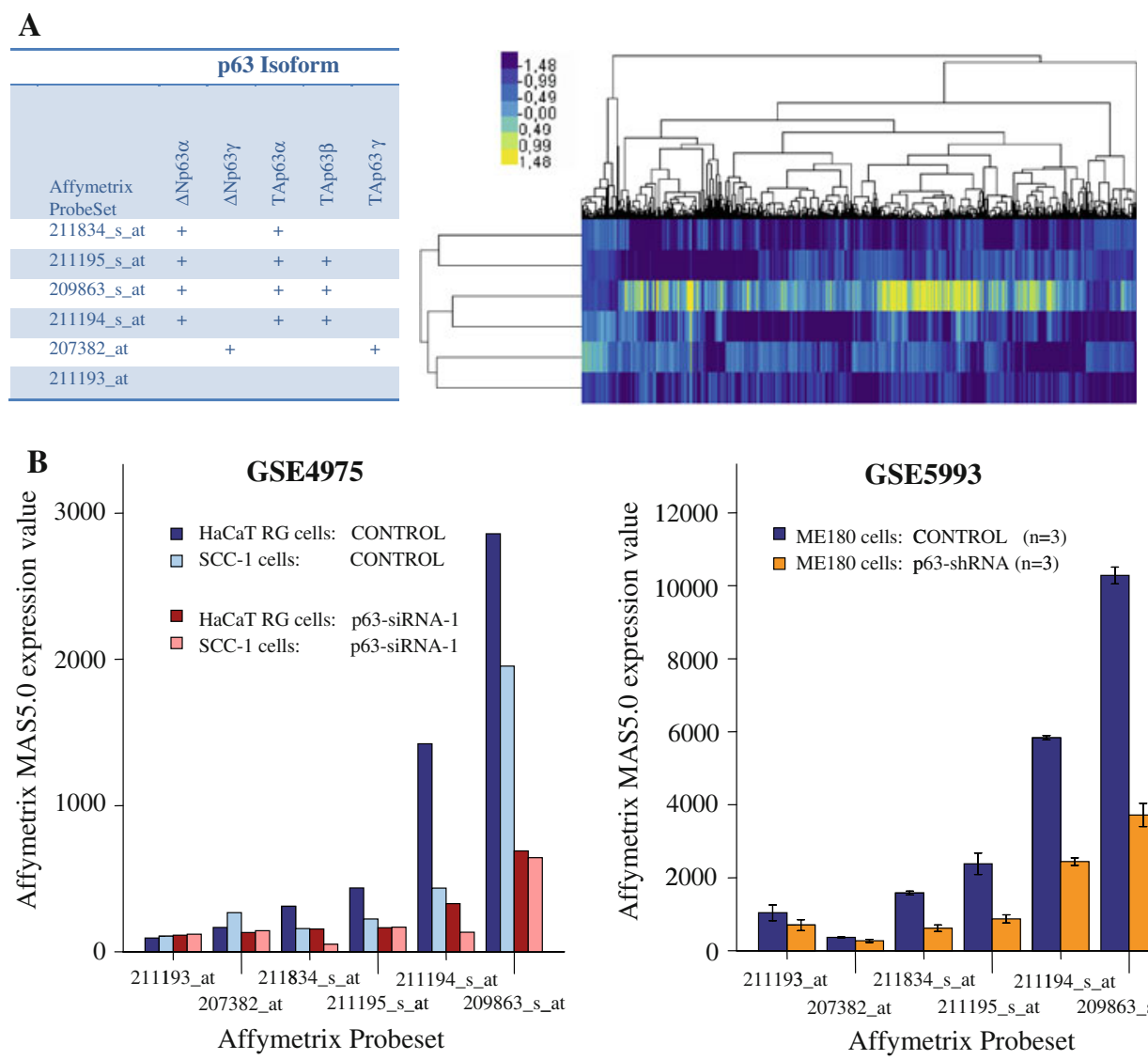

Fig. 1 P63 isoforms and corresponding Affymetrix probesets. a Six different probesets for p63 are available on the Affymetrix U133A microarray. On the left side, for each probeset a ' + ' sign marks the respective p63 isoforms which are detected by the specific probeset. On the right side, the hybridization intensity of each probeset is shown in a panel of 1,600 breast cancer samples. The color bar indicates expression strength of targed sequences (in online color

$(n=630)$. Thus, any local recurrence events are missing from these five datasets. However, as we have previously demonstrated no significant difference in relative survival was found when comparing the samples where only the DMFS endpoint was available to those using the RFS endpoint in this dataset [27]. Hence, we used in the context of this study either the RFS endpoint as disease-free survival (DFS) or the DMFS endpoint if RFS was not available. All samples were censored as of the last follow-up date or at 120 months. We constructed Kaplan-Meier curves and used the log rank test to determine the univariate significance of the variables. A Cox proportional-hazards regression model was used to examine simultaneously the effects of multiple covariates on survival. The effect of each variable was assessed with the use of the Wald test and described by the hazard ratio, with a $95 \%$ confidence interval. Subjects with missing values were excluded from the analyses, and all reported $P$ values are two sided. $P$ values of less than 0.05 were considered to indicate a

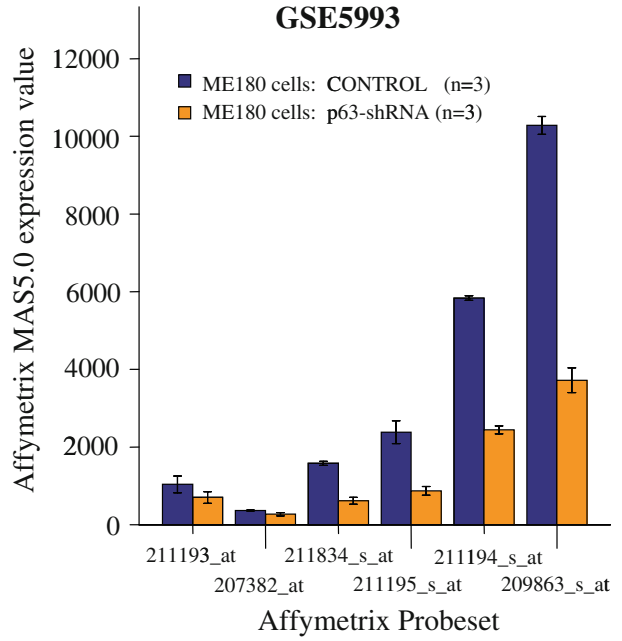

version of Figure). b Influence of p63 RNAi knockdown on the signal detected by different Affymetrix p63 probesets. Affymetrix MAS5.0 expression data of all six p63 probesets from studies of Barbieri et al. [60] (left panel; GSE4975) using siRNA and Yang et al. [61] (right panel; GSE5993) using shRNA to target p63 mRNA. In both datasets, the largest fold difference is observed for Affymetrix probeset 209863_s_at

significant result. All analyses were performed using the $\mathrm{R}$ software environment (http://www.r-project.org/) and SPSS version 17.0 (SPSS Inc., Chicago, IL).

Immunohistochemistry

Paraffin sections $(2 \mathrm{~mm})$ were mounted on SuperfrostPlus slides, dewaxed in xylene, and rehydrated through graduated ethanol to water. Antigens were retrieved by microwaving sections in $10 \mathrm{mM}$ citrate buffer ( $\mathrm{pH}$ 6.0) for $20 \mathrm{~min}$ at $800 \mathrm{~W}$. Blocking was performed using antibody dilution buffer (DCS Diagnostics,Hamburg, Germany) at the room temperature for $15 \mathrm{~min}$. Subsequently, antibodies were diluted 1:100 individually in this buffer. Sections were incubated with antibodies for $1 \mathrm{~h}$ at room temperature. For negative controls, the primary antibodies were replaced with phosphate-buffered saline. For secondary antibody incubations and detection, the Dako REAL Detection System Alkaline Phosphatase/RED (Dako, 
Glostrup, Denmark) was used following the protocol of the supplier and sections were counterstained with Mayer's hematoxylin. Antibodies used in this work were: P63 (Dako, Glostrup, Denmark, clone 4a4 code, M7247), ER (Novo Castra, Clone 6F11, NCL-ER-6F11), KRT14 (Thermo scientific, clone LL002, Ms-115-P0), Cav1 (Cell Signalling, cat 3238), AQP1 (Chemicon, cat AB3065). Secondary goat anti-rabbit antibody (FAST-RED) was purchased from Dianova (Hamburg, Germany).

\section{Results}

Analysis of p63 Affymetrix expression data in a combined cohort of 2158 ER positive breast cancers

P63 expression has been described in ER negative basallike breast tumors. The value of p63 expression in ER positive disease is less clear. To study the role of p63 in ER positive breast cancer, we first selected all $n=2,158$ ER positive samples from a combined database of $n=3,030$ Affymetrix U133 microarrays of primary breast cancers. Since p63 expression is also found in the normal cells of the basal/myoepithelial cell layer of breast tissue, we expected that our p63 microarray expression data could be strongly confounded by normal cells in samples contaminated with benign tissue. We therefore intended to exclude all those samples from our analyses which are presumed to contain large amounts of such tissue. A scatter plot comparing the expression of cytokeratins 5 (KRT5) and 14 (KRT14) was used to identify tumor samples containing measurable amounts of normal breast tissue. Both KRT5 and KRT14 are markers for normal basal cells of the breast $[63,64]$ and were found to be expressed in less than 10 percent of ER positive breast cancers [65]. As shown in Fig. 2, correlation between KRT5 and KRT14 is most stringent for samples displaying KRT14 values above zero (cutoff " $A$ " in Fig. 2; median-centered $\log _{2}$ expression values), suggesting that those tumors contain certain amounts of benign tissue. Thus, in this article, we henceforth refer to the samples with low KRT14 expression as "pure tumor samples" while those samples with high KRT14 values are referred to as "mixed tumor tissue samples". To estimate the amount of non-malignant breast tissue in tumor samples, we included data from $n=140$ normal breast biopsies [56] in the scatter plot analysis. Most of these normal breast samples displayed KRT14 values above cutoff $C$ in Fig. 2. When assuming a linear relationship between KRT14 expression values and the proportion of benign breast tissue one could estimate less than $6.25 \%$ contaminating normal tissue for samples below cutoff $A$. The intermediate cutoff $B$ in Fig. 2 would correspond to roughly $25 \%$ contaminating normal tissue in the

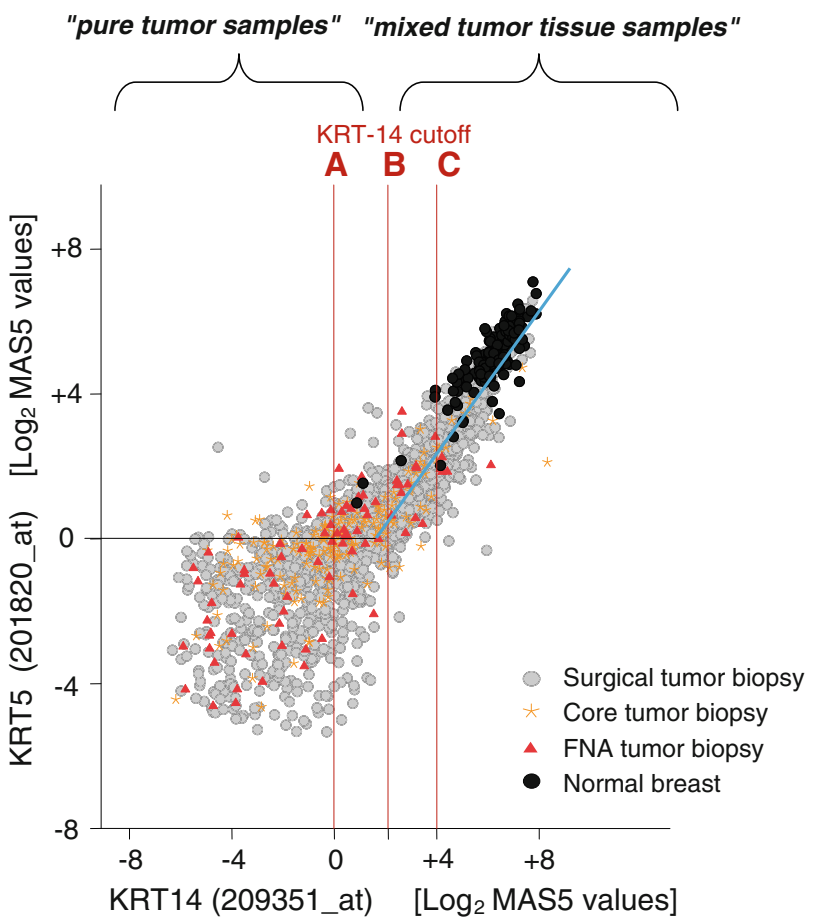

Fig. 2 Scatter plot of the expression of KRT5 and KRT14 in the combined dataset. The expression of KRT5 and KRT14 among 2158 ER positive breast cancer samples is shown in a scatter plot on $\log _{2}$ scale. Correlation is most stringent for KRT14 values above zero (cutoff $A$ ), suggesting the presence of benign tissue in those tumor samples. In addition, data from $n=140$ normal breast biopsies [56] (black dots) were included in the scatter plot most of which display KRT14 values above cutoff $C$ (16 fold higher than cutoff $A$ ). Breast cancer biopsies which were obtained by fine needle aspiration (FNA) are represented by triangles (red in online color version of Figure). $76.5 \%$ of these FNA samples which generally contain a high proportion of carcinoma cells have KRT14 values below the intermediate cutoff $B$ (fourfold higher than cutoff $A$ ). The three cutoffs $(A, B$, and $C$ ) of KRT14 expression were operationally applied to stratify "pure tumor samples" and "mixed tumor tissue samples" in subsequent analyses

biopsy. This approximation would be in line with the observation that more than three quarters of those samples which were obtained by fine needle biopsies (FNA) fall below cutoff $B$ (Fig. 2). Since it is known that this sample collection method generally produces tumor specimens containing $>90 \%$ tumor cells [47].

To analyse p63 expression in tumors without confounding by contaminating benign tissue, we first used the most stringent cutoff $A$ from Fig. 2 to split the total collective. $612(28.4 \%)$ of the 2,158 samples had KRT14 expression values below this cutoff (see also Supplementary Figure $\mathrm{S} 1$ for detailed sample numbers of all analyses). Further support for the cutoff value came from the observation that among the "mixed tumor tissue samples" (KRT14 $\geq$ cutoff $A$ ) a strong correlation of p63 and KRT5 was demonstrated by scatter plot analysis suggesting that benign tissue is the source of expression of both markers in 
these samples. In contrast, this correlation was lost in the "pure tumor samples" (Supplementary Figure S2). Importantly, despite this loss of correlation a significant expression of p63 was detectable in a subset of the "pure tumor samples".

To analyze whether carcinoma cells are the source of p63 expression in the samples, we next stained breast tumors from the Frankfurt cohort by immunohistochemistry. Exemplary results from immunohistochemistry of a tumor sample classified as "pure" by KRT14 below cutoff $A$ are depicted in Fig. 3. Strong nuclear staining of p63 in tumor cells was observed in both samples while antibodies against myoepithelial markers like KRT14, KRT5, CAV1, and AQP1 failed to react suggesting the absence of normal basal cells.

Prognostic and predictive impact of p63 expression in ER positive cancers

To analyze whether the differences in p63 expression among these $n=612$ ER positive "pure tumor samples" (KRT14 $<0$, most stringent cutoff $A$ ) are associated with a different clinical course of disease Kaplan-Meier analyses were performed. For 410 of the 612 samples, follow-up was available (Supplementary Figure S1). As shown in Fig. 4a, we observed a better prognosis for those patients with high expression of p63 $(P=0.036)$ using the median split. In contrast, when we performed the same analysis using the "mixed tumor tissue samples" (KRT14 $\geq$ cutoff $A$ ) with available follow-up $(n=1,138)$ no difference in prognosis was found (Fig. $4 \mathrm{~b}$ ). These results suggest that the differences in p63 expression among those "mixed tumor tissue samples" simply represent a confounding effect by tissue composition of the respective samples. It should be noted that other reports on p63 in breast cancer $[66,67]$ suggest that only a small fraction of samples $(<10 \%)$ express the gene. Thus, a median splitting as performed in our analyses would obviously overestimate the number of true p63 positive samples. However, as depicted in Supplementary Figure S3, reducing the number of p63 positive samples by using the upper quartile did not change its prognostic relevance.

The observed differences in prognosis according to p63 expression in the subset of "pure tumor samples" might represent a true prognostic or rather a predictive effect since many of the ER positive patients are treated with endocrine therapy. Thus, we further stratified the patients according to their systemic treatment. For 334 of the 612 samples (KRT14 below cutoff $A$ ), both treatment information and follow-up data were available (see Supplementary Figure S1). 148 of the patients were untreated, while 186 received endocrine treatment only. Interestingly, a better prognosis of those samples with high p63
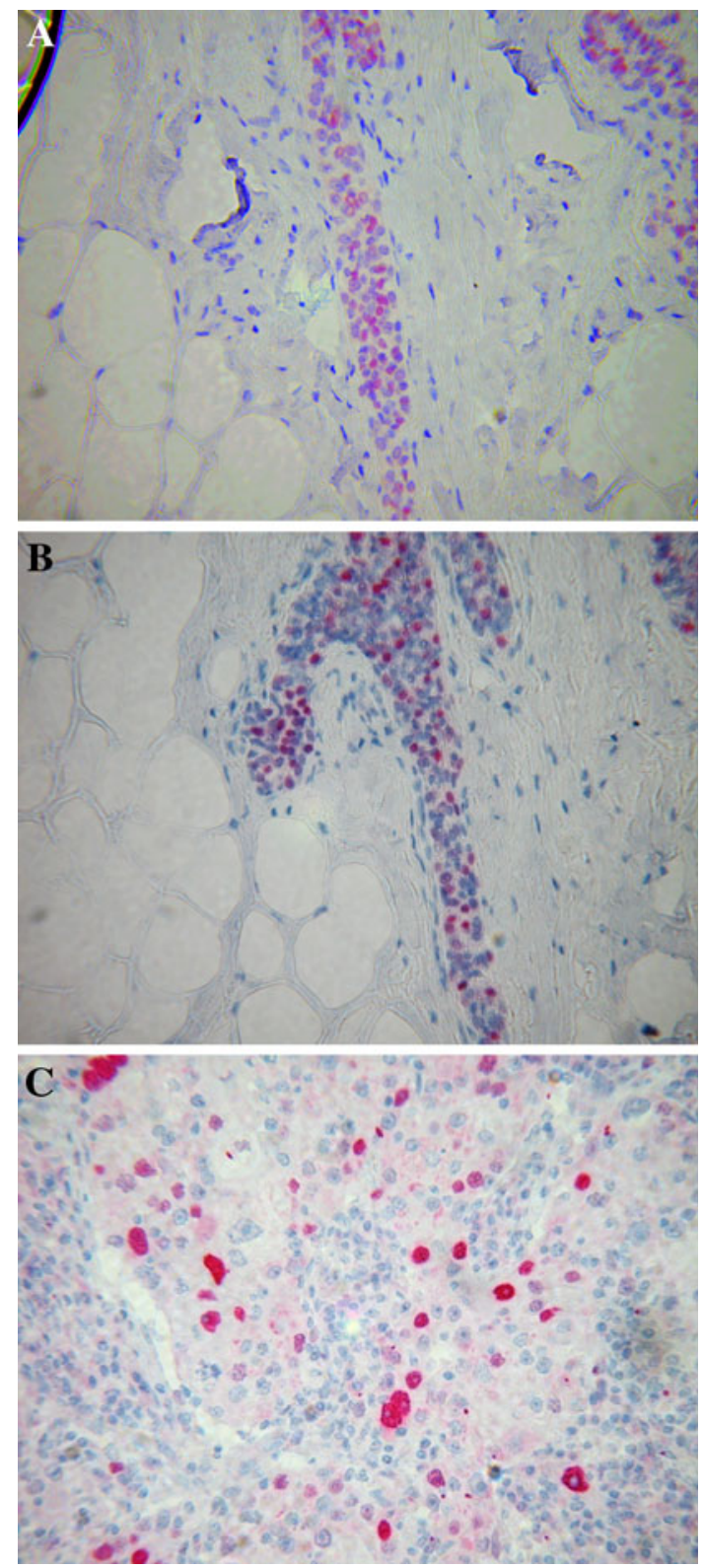

Fig. 3 P63 immunohistochemistry of "pure tumor samples" Breast cancer samples devoid of KRT14 expression as judged by microarray analyses ("pure tumor samples", cutoff $A$ from Fig. 2) were stained with antibodies against p63 and ER. Two serial sections stained for p63 (a) and ER (b), respectively, are given. In c, a higher magnification of a second sample stained for p63 is shown to demonstrate that the p63 antigen is detected in the nucleus. In line with microarray results, the phenotype of the tumors as determined by IHC was $\mathrm{KRT} 4^{-} / \mathrm{KRT}^{-} / \mathrm{CAV}^{-} / \mathrm{AQP} 1^{-}$, indicating the absence of normal myoepithelial cells. Counterstain: Mayer's hematoxylin

expression was only found in the group of endocrine treated patients (trend $P=0.06$, Fig. 5a). In contrast the difference in prognosis was smaller in the untreated population $(P=0.5$, Fig. $5 \mathrm{~b})$ suggesting a predictive value of p63 expression for endocrine treatment. We repeated this analysis by using the less stringent cutoff $B$ and cutoff $C$ 
A

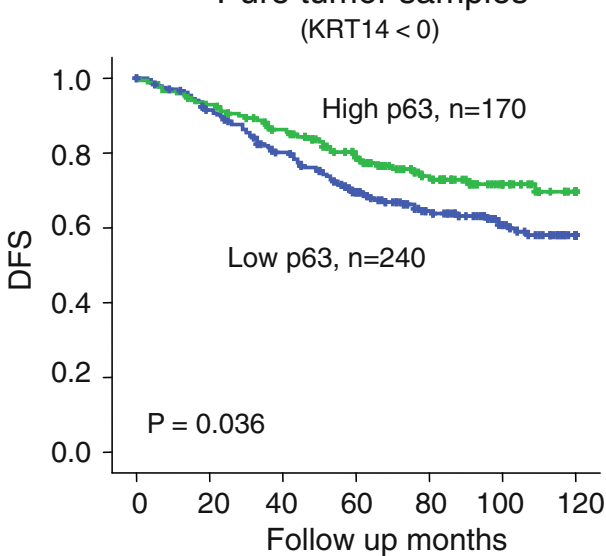

Fig. 4 Prognostic value of p63 in ER positive of breast cancer ER positive breast cancer samples from the combined dataset were first categorized in "pure tumor sample" $(\mathrm{KRT} 14<0)$ or "mixed tumor tissue samples" (KRT14 $\geq 0$ ) as described above (cutoff $A$ from Fig. 2). The prognostic value of p63 in these subgroups was analyzed

A

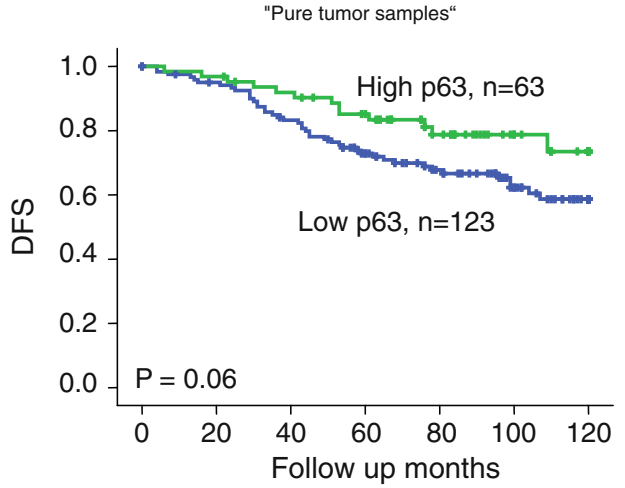

Fig. 5 Prognostic value of p63 for endocrine treated breast cancer "Pure tumor samples" (KRT14 <0) of ER positive breast cancer cases from the combined dataset were selected as in Figure 4. Survival analysis according to a median split of p63 expression was

from Fig. 2 thus including $n=674$ and $n=1,045$ samples, respectively (see Supplementary Figure S1). The results of Cox regression analysis according to p63 and standard parameters in endocrine-treated ER positive breast cancers are summarized in Table 1. Data are shown for "pure tumor samples" with low KRT14 expression according to all three cutoff values (Fig. 2a-c). In both of the larger cohorts, p63 expression displayed a predictive value in the endocrine treated group $(P=0.023$ and $P=0.043$ for cutoff $B$ and $C$, respectively) but no significant prognostic value among the untreated samples (not shown). In contrast to these results from "pure tumor samples", analyzing the "mixed tumor tissue samples" using either KRT14 cutoff $A, B$, or $C$ did not show

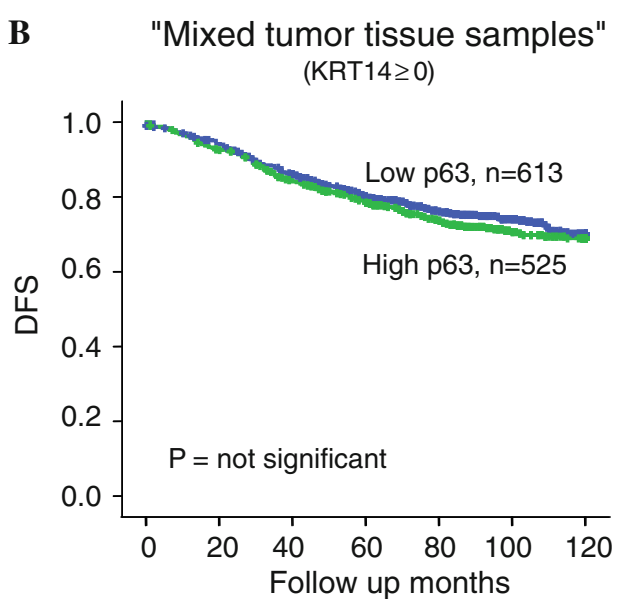

using a median split of p63 expression. Separate Kaplan-Meier analyses of disease-free survival are shown for the group "pure tumor sample" (a) and the group of "mixed tumor tissue samples" (b). (Follow-up information was available for $n=410$ of 612 samples in $A$ and $n=1,138$ of 1,546 in $B$; see Supplementary Figure S1)

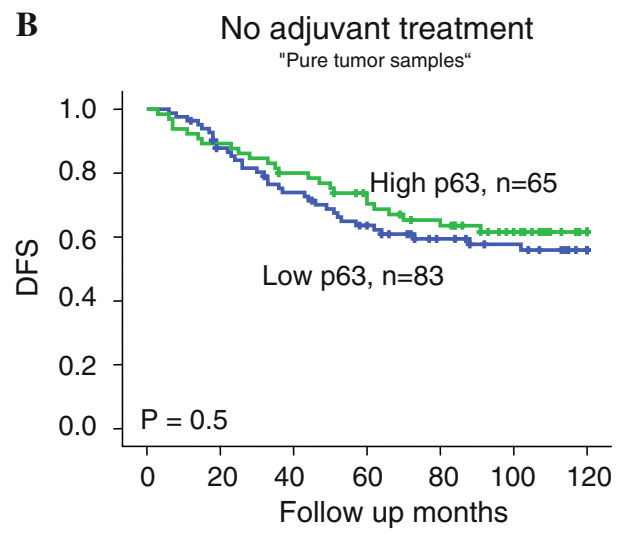

performed separately in two patient subcohorts differing in their adjuvant treatment. Kaplan-Meier graphs of disease free survival are shown either for patients with endocrine treatment (a) or no adjuvant treatment (b)

differences in disease-free survival (Supplementary Figure S4A and B).

Correlation of p63 expression with standard clinical characteristics in ER positive breast cancers

We next analyzed whether p63 expression simply represents a surrogate marker for well known clinical parameters. ER positive "pure tumor samples" were stratified according to high or low p63 expression using a simple median split. This analysis was performed for all three cohorts corresponding to the KRT14 cutoffs $A, B$, and $C$. The clinical characteristics of the respective patients are given in Table 2. In the cohort of 612 breast cancers 


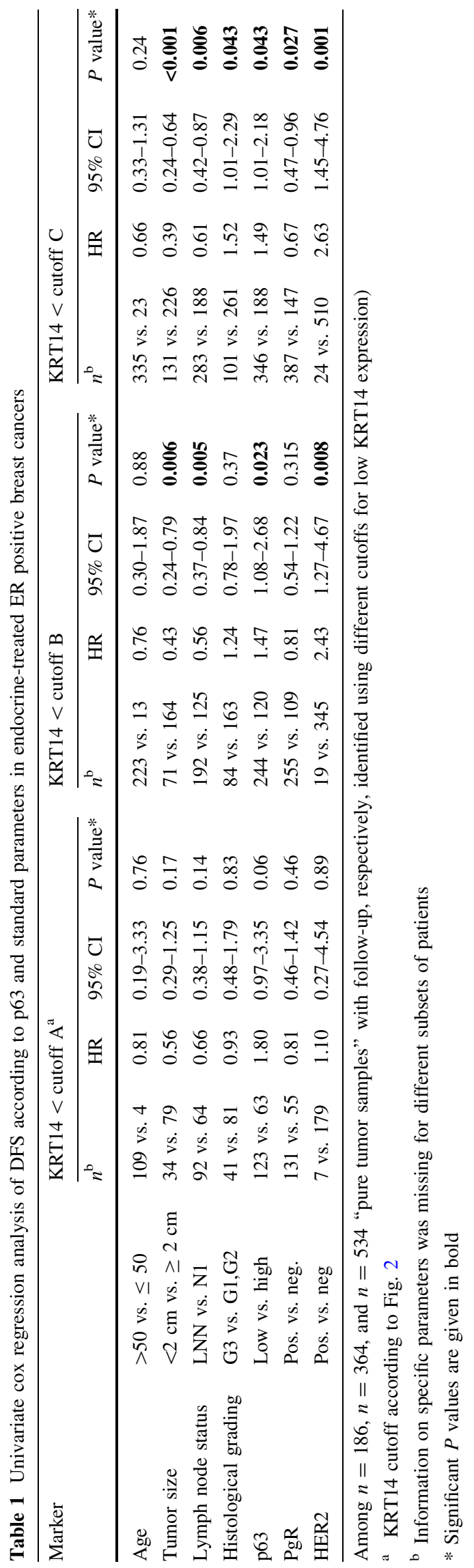

(KRT14 $<0$; cutoff $A$ ), no significant correlations were observed. In the larger cohorts, (Cutoff $B$ and $C$ for KRT14) high p63 expression was observed more frequently among younger patients $(P<0.001)$ and HER2 positive patients $(P<0.001)$. However, these associations would not explain the observed positive predictive value of p63.

\section{Discussion}

In this study, we have evaluated the role of p63 mRNA expression in ER positive breast cancer in a large scale microarray analysis. We found that "contaminating" benign tissue in "mixed tumor tissue samples" confounded the measurement of p63 expression. However, when restricting the analyses to the subset of "pure tumor samples" defined by low expression of KRT14, we were able to identify a subset of ER positive tumors still expressing p63. These tumors are characterized by a better prognosis than those without p63 expression among endocrine-treated patients (Table 1), while no prognostic value was observed for untreated patients. These clinical differences were not seen when the analyses were performed on the "mixed tumor tissue samples" suggesting that the confounding p63 expression in benign tissue in those samples precludes the correct identification of p63 expressing tumor cells.

In contrast to our results, studies of different solid tumor entities have shown that an overexpression of p63 is associated with poor clinical outcome. For instance, Iczkowski et al. demonstrated in the adenoid cystic/basal cell carcinoma of the prostate that p63 is highly overexpressed and linked to poor prognosis [68]. Moreover, p63 expression was found in highly aggressive ER negative basal-like breast cancer [14]. By analysis of various p63 isoforms, a few authors did demonstrate an overexpression of $\Delta \mathrm{Np} 63$ in different cancers $[69,70]$. The results of tumorigenicity assays indicate, that overexpression of $\Delta \mathrm{Np} 63$ led to increased colony formation in vitro and increased tumor formation in nude mice [69], suggesting an oncogenic role of this transcript variant $[22,69,70]$. In contrast to these findings, a decreased TAp63 level was reported to be associated with poor clinical outcome in ductal and laryngeal squamous cell carcinomas [71, 72]. In addition, Wang et al. were able to demonstrate an association between loss of p63 expression and progression of breast ductal carcinoma [25]. Thus, our findings are more in agreement with these latter data on p63. Furthermore, the analyses presented here indicate a predictive rather than a prognostic value of $\mathrm{p} 63$. Thus, it could be suggested that the protein is involved in apoptotic response to anticancer drugs. Immunohistochemistry of various breast cancer samples positive for p63 expression reveals that only a 


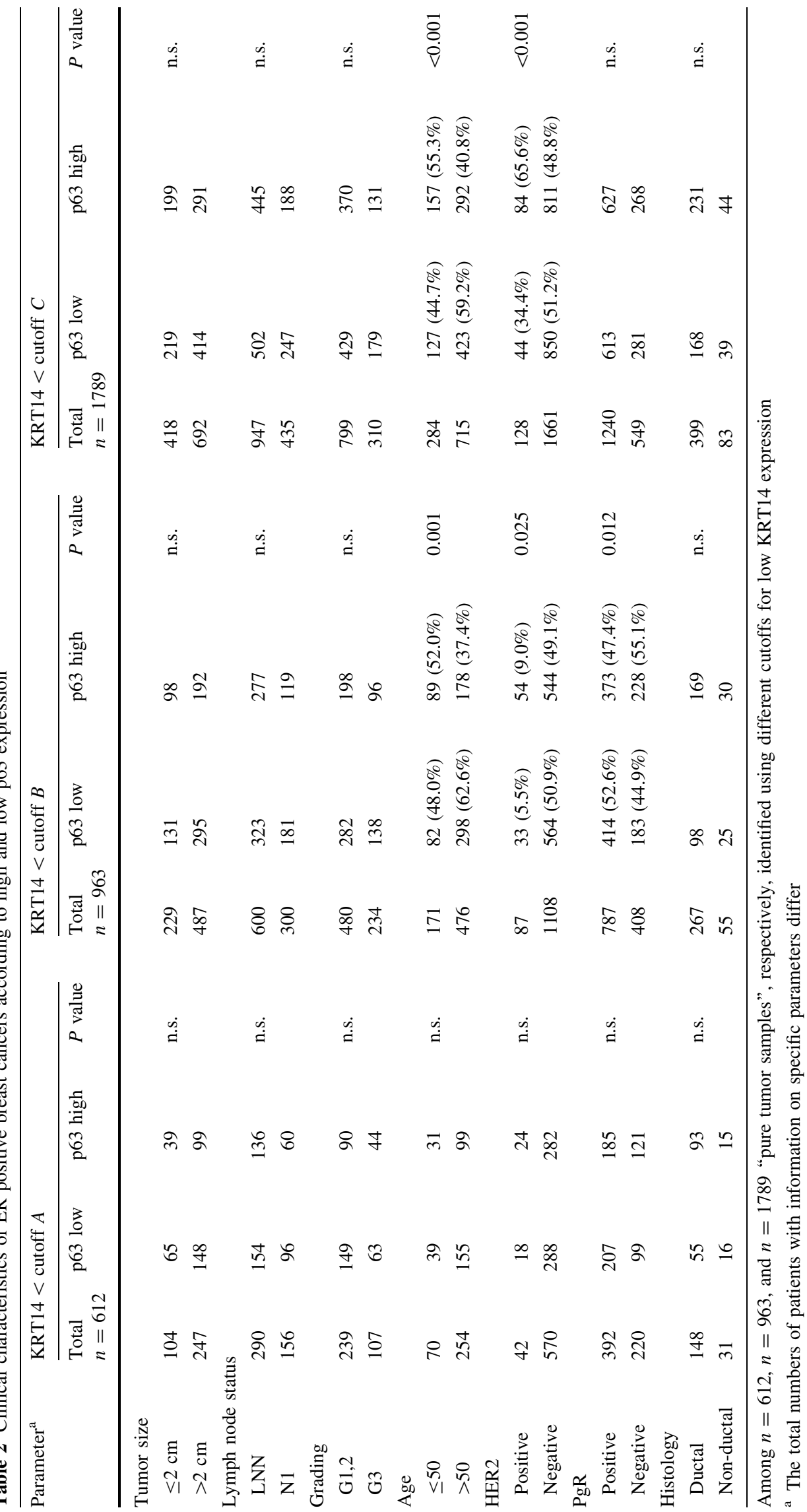


subset of the tumor cells express the gene. Therefore, a direct implication of p63 in endocrine responsiveness of breast cancer cells is unlikely. An explanation for the predictive value of p63 might be that the scattered p63 positive tumor cells represent immature precursors. The further differentiation of these precursor cells into a p63 negative phenotype could be affected by endocrine treatment. Those cells with an impaired differentiation may than underwent apoptosis. In line with the assumption, that p63 is linked to an immature phenotype are a number of reports, suggesting that loss of p63 expression is required for the transition from a basal to a luminal differentiation [66]. Moreover, p63 knockout mice are not viable and have several developmental defects such as a lack of limbs, teeth and mammary glands, structures which emerge upon epidermal-mesenchymal interactions during embryonic development [12].

Although the precise oncogenic potential of p63 remains to be elucidated, our data suggest that a prognostic value of p63 in ER positive breast cancers is only observed in endocrine treated samples. To date, the predictive importance of $\mathrm{p} 63$ has been analyzed only in a limited number of studies. Zangen et al. found, that high levels of $\Delta \mathrm{Np} 63$ in primary tumors accurately predicted response to platinumbased chemotherapy and a favorable outcome in head and neck cancer patients [73]. Previous studies have shown, that $\Delta \mathrm{Np} 63$ isoforms acts as negative regulators of proapoptotic p53/p73-pathways [74-76]. The finding of a better prognosis of patients showing high p63 expression in our study seems not to be consistent with a model of an antiapoptotic function of p63. However, high p63 expression may indicate the presence of the p53/p73-pathway, which is subsequently engaged during antiestrogenic treatment. Future studies are needed to further clarify the role of p63 in predicting response to anticancer therapy.

Acknowledgments We thank Samira Adel and Katherina Kourtis for expert technical assistance. This work was supported by grants from the Deutsche Krebshilfe, the Margarete Bonifer-Stiftung, Bad Soden, the BANSS-Stiftung, Biedenkopf, the Werner Sack-Stiftung, Essen, and the Dr. Robert Pfleger-Stiftung, Bamberg.

\section{References:}

1. McKeon F, Melino G (2007) Fog of war: the emerging p53 family. Cell cycle 6(3):229-232

2. Finlan LE, Hupp TR (2007) p63: the phantom of the tumor suppressor. Cell cycle 6(9):1062-1071

3. King KE, Weinberg WC (2007) p63: defining roles in morphogenesis, homeostasis, and neoplasia of the epidermis. Mol Carcinog 46(8):716-724

4. Yang A, Kaghad M, Wang Y, Gillett E, Fleming MD, Dotsch V, Andrews NC, Caput D, McKeon F (1998) p63, a p53 homolog at 3q27-29, encodes multiple products with transactivating, death-inducing, and dominant-negative activities. Mol cell 2(3): 305-316

5. Bourdon JC (2007) p53 and its isoforms in cancer. Br J Cancer 97(3):277-282

6. Flores ER, Tsai KY, Crowley D, Sengupta S, Yang A, McKeon F, Jacks T (2002) p63 and p73 are required for p53-dependent apoptosis in response to DNA damage. Nature 416(6880):560564

7. Irwin MS, Kaelin WG Jr (2001) Role of the newer p53 family proteins in malignancy. Apoptosis 6(1-2):17-29

8. Yang A, Schweitzer R, Sun D, Kaghad M, Walker N, Bronson RT, Tabin C, Sharpe A, Caput D, Crum C et al (1999) p63 is essential for regenerative proliferation in limb, craniofacial and epithelial development. Nature 398(6729):714-718

9. McKeon F (2004) p63 and the epithelial stem cell: more than status quo? Genes Dev 18(5):465-469

10. Barbareschi M, Pecciarini L, Cangi MG, Macri E, Rizzo A, Viale G, Doglioni C (2001) p63, a p53 homologue, is a selective nuclear marker of myoepithelial cells of the human breast. Am J Surg Pathol 25(8):1054-1060

11. DiRenzo J, Signoretti S, Nakamura N, Rivera-Gonzalez R, Sellers W, Loda M, Brown M (2002) Growth factor requirements and basal phenotype of an immortalized mammary epithelial cell line. Cancer Res 62(1):89-98

12. Mills AA, Zheng B, Wang XJ, Vogel H, Roop DR, Bradley A (1999) p63 is a p53 homologue required for limb and epidermal morphogenesis. Nature 398(6729):708-713

13. Matos I, Dufloth R, Alvarenga M, Zeferino LC, Schmitt F (2005) p63, cytokeratin 5, and P-cadherin: three molecular markers to distinguish basal phenotype in breast carcinomas. Virchows Arch 447(4):688-694

14. Sorlie T, Perou CM, Tibshirani R, Aas T, Geisler S, Johnsen H, Hastie T, Eisen MB, van de Rijn M, Jeffrey SS et al (2001) Gene expression patterns of breast carcinomas distinguish tumor subclasses with clinical implications. Proc Natl Acad Sci USA 98(19):10869-10874

15. Ribeiro-Silva A, Zambelli Ramalho LN, Britto Garcia S, Zucoloto S (2003) The relationship between p63 and p53 expression in normal and neoplastic breast tissue. Arch Pathol Lab Med 127(3):336-340

16. Reis-Filho JS, Milanezi F, Paredes J, Silva P, Pereira EM, Maeda SA, De Carvalho LV, Schmitt FC (2003) Novel and classic myoepithelial/stem cell markers in metaplastic carcinomas of the breast. Appl Immunohistochem Mol Morphol 11(1):1-8

17. Flores ER, Sengupta S, Miller JB, Newman JJ, Bronson R, Crowley D, Yang A, McKeon F, Jacks T (2005) Tumor predisposition in mice mutant for $\mathrm{p} 63$ and p73: evidence for broader tumor suppressor functions for the p53 family. Cancer Cell 7(4):363-373

18. Keyes WM, Vogel H, Koster MI, Guo X, Qi Y, Petherbridge KM, Roop DR, Bradley A, Mills AA (2006) p63 heterozygous mutant mice are not prone to spontaneous or chemically induced tumors. Proc Natl Acad Sci USA 103(22):8435-8440

19. Yamaguchi K, Wu L, Caballero OL, Hibi K, Trink B, Resto V, Cairns P, Okami K, Koch WM, Sidransky D et al (2000) Frequent gain of the p40/p51/p63 gene locus in primary head and neck squamous cell carcinoma. Int J Cancer 86(5):684-689

20. Uramoto H, Sugio K, Oyama T, Nakata S, Ono K, Nozoe T, Yasumoto K (2006) Expression of the p53 family in lung cancer. Anticancer Res 26(3A): 1785-1790

21. Takeuchi Y, Tamura A, Kamiya M, Fukuda T, Ishikawa O (2005) Immunohistochemical analyses of p63 expression in cutaneous tumours. Br J Dermatol 153(6):1230-1232

22. Lin Z, Liu M, Li Z, Kim C, Lee E, Kim I (2006) DeltaNp63 protein expression in uterine cervical and endometrial cancers. J Cancer Res Clin Oncol 132(12):811-816 
23. Quade BJ, Yang A, Wang Y, Sun D, Park J, Sheets EE, Cviko A, Federschneider JM, Peters R, McKeon FD et al (2001) Expression of the p53 homologue p63 in early cervical neoplasia. Gynecol Oncol 80(1):24-29

24. Reis-Filho JS, Schmitt FC (2003) p63 expression in sarcomatoid/ metaplastic carcinomas of the breast. Histopathology 42(1):94-95

25. Wang X, Mori I, Tang W, Nakamura M, Nakamura Y, Sato M, Sakurai T, Kakudo K (2002) p63 expression in normal, hyperplastic and malignant breast tissues. Breast Cancer 9(3):216-219

26. Mills AA (2006) p63 oncogene or tumor suppressor? Curr Opin Genet Dev 16(1):38-44

27. Karn T, Metzler D, Ruckhaberle E, Hanker L, Gatje R, Solbach C, Ahr A, Schmidt M, Holtrich U, Kaufmann M et al (2009) Data driven derivation of cutoffs from a pool of 3,030 Affymetrix arrays to stratify distinct clinical types of breast cancer. Breast Cancer Res Treat. doi:10.1007/s10549-009-0416-z

28. Ahr A, Karn T, Solbach C, Seiter T, Strebhardt K, Holtrich U, Kaufmann M (2002) Identification of high risk breast-cancer patients by gene expression profiling. Lancet 359(9301):131-132

29. Rody A, Holtrich U, Gaetje R, Gehrmann M, Engels K, von Minckwitz G, Loibl S, Diallo-Danebrock R, Ruckhaberle E, Metzler D et al (2007) Poor outcome in estrogen receptor-positive breast cancers predicted by loss of plexin B1 (2007) Clin Cancer Res 13(4):1115-1122

30. Rody A, Karn T, Ruckhaberle E, Hanker L, Metzler D, Muller V, Solbach C, Ahr A, Gatje R, Holtrich U et al (2009) Loss of Plexin B1 is highly prognostic in low proliferating ER positive breast cancers-results of a large scale microarray analysis. Eur $\mathbf{J}$ Cancer 45(3):405-413

31. Rody A, Karn T, Solbach C, Gaetje R, Munnes M, Kissler S, Ruckhaberle E, Minckwitz GV, Loibl S, Holtrich U et al (2007) The erbB2+ cluster of the intrinsic gene set predicts tumor response of breast cancer patients receiving neoadjuvant chemotherapy with docetaxel, doxorubicin and cyclophosphamide within the GEPARTRIO trial. Breast 16(3):235-240

32. Ruckhaberle E, Rody A, Engels K, Gaetje R, von Minckwitz G, Schiffmann S, Grosch S, Geisslinger G, Holtrich U, Karn T et al (2008) Microarray analysis of altered sphingolipid metabolism reveals prognostic significance of sphingosine kinase 1 in breast cancer. Breast Cancer Res Treat 112(1):41-52

33. Wang Y, Klijn JG, Zhang Y, Sieuwerts AM, Look MP, Yang F, Talantov D, Timmermans M, Meijer-van Gelder ME, Yu J et al (2005) Gene-expression profiles to predict distant metastasis of lymph-node-negative primary breast cancer. Lancet 365(9460): 671-679

34. Minn AJ, Gupta GP, Padua D, Bos P, Nguyen DX, Nuyten D, Kreike B, Zhang Y, Wang Y, Ishwaran H et al (2007) Lung metastasis genes couple breast tumor size and metastatic spread. Proc Natl Acad Sci U S A 104(16):6740-6745

35. Creighton CJ, Kent Osborne C, van de Vijver MJ, Foekens JA, Klijn JG, Horlings HM, Nuyten D, Wang Y, Zhang Y, Chamness GC et al (2009) Molecular profiles of progesterone receptor loss in human breast tumors. Breast Cancer Res Treat 114(2):287-299

36. Schmidt M, Bohm D, von Torne C, Steiner E, Puhl A, Pilch H, Lehr HA, Hengstler JG, Kolbl H, Gehrmann M (2008) The humoral immune system has a key prognostic impact in nodenegative breast cancer. Cancer Res 68(13):5405-5413

37. Desmedt C, Piette F, Loi S, Wang Y, Lallemand F, Haibe-Kains B, Viale G, Delorenzi M, Zhang Y, d'Assignies MS et al (2007) Strong time dependence of the 76-gene prognostic signature for node-negative breast cancer patients in the TRANSBIG multicenter independent validation series. Clin Cancer Res 13(11): 3207-3214

38. Sotiriou C, Wirapati P, Loi S, Harris A, Fox S, Smeds J, Nordgren H, Farmer P, Praz V, Haibe-Kains B et al (2006) Gene expression profiling in breast cancer: understanding the molecular basis of histologic grade to improve prognosis. J Natl Cancer Inst 98(4):262-272

39. Loi S, Haibe-Kains B, Desmedt C, Wirapati P, Lallemand F, Tutt AM, Gillet C, Ellis P, Ryder K, Reid JF et al (2008) Predicting prognosis using molecular profiling in estrogen receptor-positive breast cancer treated with tamoxifen. BMC Genomics 9:239

40. Loi S, Haibe-Kains B, Desmedt C, Lallemand F, Tutt AM, Gillet C, Ellis P, Harris A, Bergh J, Foekens JA et al (2007) Definition of clinically distinct molecular subtypes in estrogen receptorpositive breast carcinomas through genomic grade. J Clin Oncol 25(10):1239-1246

41. Zhang Y, Sieuwerts AM, McGreevy M, Casey G, Cufer T, Paradiso A, Harbeck N, Span PN, Hicks DG, Crowe J et al (2009) The 76-gene signature defines high-risk patients that benefit from adjuvant tamoxifen therapy. Breast Cancer Res Treat 116:303309

42. Pawitan Y, Bjohle J, Amler L, Borg AL, Egyhazi S, Hall P, Han X, Holmberg L, Huang F, Klaar S et al (2005) Gene expression profiling spares early breast cancer patients from adjuvant therapy: derived and validated in two population-based cohorts. Breast Cancer Res 7(6):R953-R964

43. Miller LD, Smeds J, George J, Vega VB, Vergara L, Ploner A, Pawitan Y, Hall P, Klaar S, Liu ET et al (2005) An expression signature for $\mathrm{p} 53$ status in human breast cancer predicts mutation status, transcriptional effects, and patient survival. Proc Natl Acad Sci USA 102(38):13550-13555

44. Ivshina AV, George J, Senko O, Mow B, Putti TC, Smeds J, Lindahl T, Pawitan Y, Hall P, Nordgren H et al (2006) Genetic reclassification of histologic grade delineates new clinical subtypes of breast cancer. Cancer Res 66(21):10292-10301

45. Chin K, DeVries S, Fridlyand J, Spellman PT, Roydasgupta R, Kuo WL, Lapuk A, Neve RM, Qian Z, Ryder T et al (2006) Genomic and transcriptional aberrations linked to breast cancer pathophysiologies. Cancer Cell 10(6):529-541

46. Minn AJ, Gupta GP, Siegel PM, Bos PD, Shu W, Giri DD, Viale A, Olshen AB, Gerald WL, Massague J (2005) Genes that mediate breast cancer metastasis to lung. Nature 436(7050):518-524

47. Hess KR, Anderson K, Symmans WF, Valero V, Ibrahim N, Mejia JA, Booser D, Theriault RL, Buzdar AU, Dempsey PJ et al (2006) Pharmacogenomic predictor of sensitivity to preoperative chemotherapy with paclitaxel and fluorouracil, doxorubicin, and cyclophosphamide in breast cancer. J Clin Oncol 24(26):42364244

48. Farmer P, Bonnefoi H, Becette V, Tubiana-Hulin M, Fumoleau P, Larsimont D, Macgrogan G, Bergh J, Cameron D, Goldstein D et al (2005) Identification of molecular apocrine breast tumours by microarray analysis. Oncogene 24(29):4660-4671

49. Miller WR, Larionov AA, Renshaw L, Anderson TJ, White S, Murray J, Murray E, Hampton G, Walker JR, Ho S et al (2007) Changes in breast cancer transcriptional profiles after treatment with the aromatase inhibitor, letrozole. Pharmacogenet Genomics 17(10):813-826

50. The International Genomics Consortium (IGC) (2005) The expO project (expression project for oncology) http://www.intgen.org/

51. Yu K, Ganesan K, Tan LK, Laban M, Wu J, Zhao XD, Li H, Leung CH, Zhu Y, Wei CL et al (2008) A precisely regulated gene expression cassette potently modulates metastasis and survival in multiple solid cancers. PLoS Genet 4(7):e1000129

52. Gene Expression Omnibus Series GSE12763 (2009) http://www. ncbi.nlm.nih.gov/geo/query/acc.cgi?acc=GSE12763

53. Richardson AL, Wang ZC, De Nicolo A, Lu X, Brown M, Miron A, Liao X, Iglehart JD, Livingston DM, Ganesan S (2006) X chromosomal abnormalities in basal-like human breast cancer. Cancer Cell 9(2):121-132

54. Klein A, Wessel R, Graessmann M, Jurgens M, Petersen I, Schmutzler R, Niederacher D, Arnold N, Meindl A, Scherneck S 
et al (2007) Comparison of gene expression data from human and mouse breast cancers: identification of a conserved breast tumor gene set. Int J Cancer 121(3):683-688

55. Marty B, Maire V, Gravier E, Rigaill G, Vincent-Salomon A, Kappler M, Lebigot I, Djelti F, Tourdes A, Gestraud P et al (2008) Frequent PTEN genomic alterations and activated phosphatidylinositol 3-kinase pathway in basal-like breast cancer cells. Breast Cancer Res 10(6):R101

56. Chen DT, Nasir A, Culhane A, Venkataramu C, Fulp W, Rubio R, Wang T, Agrawal D, McCarthy SM, Gruidl M et al (2009) Proliferative genes dominate malignancy-risk gene signature in histologically-normal breast tissue. Breast Cancer Res Treat. doi: 10.1007/s10549-009-0344-y

57. Affymetrix (2001) Statistical algorithms reference guide, Technical report. Affymetrix, Santa Clara

58. Gautier L, Cope L, Bolstad BM, Irizarry RA (2004) affyanalysis of Affymetrix GeneChip data at the probe level. Bioinformatics 20(3):307-315

59. Gentleman RC, Carey VJ, Bates DM, Bolstad B, Dettling M, Dudoit S, Ellis B, Gautier L, Ge Y, Gentry J et al (2004) Bioconductor: open software development for computational biology and bioinformatics. Genome Biol 5(10):R80

60. Barbieri CE, Tang LJ, Brown KA, Pietenpol JA (2006) Loss of p63 leads to increased cell migration and up-regulation of genes involved in invasion and metastasis. Cancer Res 66(15):75897597

61. Yang A, Zhu Z, Kapranov P, McKeon F, Church GM, Gingeras TR, Struhl K (2006) Relationships between p63 binding, DNA sequence, transcription activity, and biological function in human cells. Mol Cell 24(4):593-602

62. McShane LM, Altman DG, Sauerbrei W, Taube SE, Gion M, Clark GM (2006) REporting recommendations for tumor MARKer prognostic studies (REMARK). Breast Cancer Res Treat 100(2):229-235

63. Debus E, Weber K, Osborn M (1982) Monoclonal cytokeratin antibodies that distinguish simple from stratified squamous epithelia: characterization on human tissues. The EMBO journal 1(12):1641-1647

64. Nagle RB, Bocker W, Davis JR, Heid HW, Kaufmann M, Lucas DO, Jarasch ED (1986) Characterization of breast carcinomas by two monoclonal antibodies distinguishing myoepithelial from luminal epithelial cells. J Histochem Cytochem 34(7):869-881

65. Abd El-Rehim DM, Pinder SE, Paish CE, Bell J, Blamey RW, Robertson JF, Nicholson RI, Ellis IO (2004) Expression of luminal and basal cytokeratins in human breast carcinoma. J Pathol 203(2):661-671
66. Ribeiro-Silva A, Ramalho LN, Garcia SB, Brandao DF, Chahud F, Zucoloto S (2005) p63 correlates with both BRCA1 and cytokeratin 5 in invasive breast carcinomas: further evidence for the pathogenesis of the basal phenotype of breast cancer. Histopathology 47(5):458-466

67. Reis-Filho JS, Simpson PT, Martins A, Preto A, Gartner F, Schmitt FC (2003) Distribution of p63, cytokeratins 5/6 and cytokeratin 14 in 51 normal and 400 neoplastic human tissue samples using TARP-4 multi-tumor tissue microarray. Virchows Arch 443(2):122-132

68. Czkowski KA, Ferguson KL, Grier DD, Hossain D, Banerjee SS, McNeal JE, Bostwick DG (2003) Adenoid cystic/basal cell carcinoma of the prostate: clinicopathologic findings in 19 cases. Am J Surg Pathol 27(12):1523-1529

69. Hibi K, Trink B, Patturajan M, Westra WH, Caballero OL, Hill DE, Ratovitski EA, Jen J, Sidransky D (2000) AIS is an oncogene amplified in squamous cell carcinoma. Proc Natl Acad Sci USA 97(10):5462-5467

70. Senoo M, Tsuchiya I, Matsumura Y, Mori T, Saito Y, Kato H, Okamoto T, Habu S (2001) Transcriptional dysregulation of the p73L/p63/p51/p40/KET gene in human squamous cell carcinomas: expression of Delta Np73L, a novel dominant-negative isoform, and loss of expression of the potential tumour suppressor p51. Br J Cancer 84(9):1235-1241

71. Pruneri G, Pignataro L, Manzotti M, Carboni N, Ronchetti D, Neri A, Cesana BM, Viale G (2002) p63 in laryngeal squamous cell carcinoma: evidence for a role of TA-p63 down-regulation in tumorigenesis and lack of prognostic implications of p63 immunoreactivity. Lab Investig 82(10):1327-1334

72. Chen YK, Hsue SS, Lin LM (2004) Expression of p63 (TA and deltaN isoforms) in human primary well differentiated buccal carcinomas. Int J Oral Maxillofac Surg 33(5):493-497

73. Zangen R, Ratovitski E, Sidransky D (2005) DeltaNp63alpha levels correlate with clinical tumor response to cisplatin. Cell cycle 4(10):1313-1315

74. Rocco JW, Leong CO, Kuperwasser N, DeYoung MP, Ellisen LW (2006) p63 mediates survival in squamous cell carcinoma by suppression of p73-dependent apoptosis. Cancer Cell 9(1):45-56

75. DeYoung MP, Johannessen CM, Leong CO, Faquin W, Rocco JW, Ellisen LW (2006) Tumor-specific p73 up-regulation mediates p63 dpendence in squamous cell carcinoma. Cancer Res 66(19):9362-9368

76. Leong CO, Vidnovic N, DeYoung MP, Sgroi D, Ellisen LW (2007) The p63/p73 network mediates chemosensitivity to cisplatin in a biologically defined subset of primary breast cancers. $\mathbf{J}$ Clin Investig 117(5):1370-1380 